\title{
ANALISIS PENAWARAN DAN PERMINTAAN BAWANG MERAH DI PROVINSI JAWA BARAT
}

\author{
Pandi Pardian ${ }^{1}$, Trisna Insan Noor ${ }^{2}$, Achdya Kusumah ${ }^{3}$ \\ ${ }^{1,2}$ Dosen di Prodi Agribisnis Faperta Unpad, Bandung \\ ${ }^{3}$ Staf Peneliti di Puslitbang Inovasi dan Kelembagaan LPPM Unpad \\ Email:pandip3@gmail.com
}

\begin{abstract}
ABSTRAK
Bawang merah (Allium ascalonicum L) merupakan sayuran rempah yang umum dikonsumsi oleh masyarakat di Indonesia. BPS memperkirakan bahwa kenaikan harga bawang merah merupakan penyebab terbesar ke dua setelah kenaikan BBM pada bulan Maret 2015. Rendahnya tingkat produktivitas bawang merah dan karakteristik produksi bawang merah yang bergantung pada musim tidak mampu mengimbangi tingkat permintaan yang cenderung konstan. Kondisi ini menyebabkan kesenjangan (gap) antara pasokan (supply) dan permintaan (demand) sehingga menyebabkan fluktuasi harga antar waktu. Penelitian ini menganalisa permintaan dan penawaran bawang merah di Indonesia sehingga dapat dihasilkan rekomendasi kebijakan pengembangan bawang merah dengan melihat aspek penawaran dan permintaan. Penelitian ini menggunakan metode analisis penawaran dan permintaan bawang merah yang dilakukan secara kualitatif; serta analisis proyeksi pemetaan penawaran dan permintaan bawang merah dilakukan secara kuantitatif. Hasil penelitian menunjukkan bahwa pola produksi bawang merah Jawa Barat sangat dipengaruhi oleh 5 kabupaten sentra produksi utama (Cirebon, Bandung, Majalengka, Garut, Kuningan). Produktivitas bawang merah relatif stagnan karena belum terjadi perubahan yang signifikan terkait dengan teknologi budidaya dan pasca panen untuk meningkatkan produktivitas. Di sisi permintaan, tingkat permintaan bawang merah cenderung mengikuti kenaikan jumlah penduduk. Ini menyebabkan Jawa Barat selalu defisit dalam ketersediaan bawang merah.
\end{abstract}

Kata kunci: bawang merah, fluktuasi harga, penawaran, permintaan

\section{ABSTRACT}

Shallot (Allium ascalonicum L.) is one of the vegetables consumed by people in Indonesia. Bureau of Statistics data shows that the increase of shallot price is the second most contributing factor after the rising petroleum price to the national inflation in March 2015. Low productivity and its seasonal production characteristics became hindrances at the production level, and thus limiting supply capability to meet the demand. This situation has affected the supply and demand equilibrium by creating a gap which leads to market price fluctuation. This study analyses shallot's supply and demand in order to formulate recommendations to the policy makers so that they are able to support the development of shallot by including the supply and demand elements in their policies. This study utilizes qualitative and quantitative research methods in analyzing and mapping shallot's supply and demand. The results show that shallot's national production is concentrated in 5 provinces (Central Java, East Java, West Java, West Nusa Tenggara, and West Sumatera). The productivity is relatively low and stagnant due to limited access to technology and good agricultural practices, in both preand post-harvest activities. As for the demand side, due to shallot's inelastic characteristic, the demand is constantly growing as the population gets higher. This condition has caused West Java to be in a constant deficit situation for shallot.

Keywords: shallot, price fluctuation, supply, demand

\section{PENDAHULUAN}

Bawang merah (Allium ascalonicum L) merupakan sayuran rempah yang dikonsumsi oleh rumah tangga masyarakat Indonesia sebagai bumbu masakan sehari-hari dan selain sebagai bahan baku industri, sehingga permintaan akan bawang merah berbanding lurus dengan peningkatan jumlah penduduk untuk kebutuhan rumah tangga dan kebutuhan industri.

Salah satu produsen dan konsumen bawang merah terbesar di dunia adalah Indonesia. Beberapa negara di Asia Tenggara 
seperti Malaysia, Thailand, Philipina juga sebagai produsen dan konsumen tapi tingkat konsumsinya lebih rendah dibandingkan dengan Indonesia sehingga sebagian besar produksinya ditujukan untuk ekspor terutama ke Indonesia.

Produksi bawang merah cenderung musiman karena dipengaruhi beberapa hal namun permintaan sepanjang tahun cenderung merata sehingga seringkali kondisi tersebut menyebabkan terjadinya gejolak baik jumlah maupun harga karena adanya kesenjangan (gap) antara pasokan (supply) dan permintaan (demand).

Pada Tahun 2013 produksi bawang merah di Provinsi Jawa Barat sebesar 98,42 persen dihasilkan oleh 5 sentra produksi utama yaitu Kabupaten Cirebon (31,53\%), Kabupaten Majalengka (20,49\%), Kabupaten Bandung (27,41\%) dan Kabupaten Garut (17,07\%), sementara Kabupaten Kuningan (1,92 \%) selain memproduksi bawang merah segar juga merupakan sentra utama produk olahan bawang goreng untuk kepentingan industri pengolahan. Produksi yang dihasilkan oleh ke 5 kabupaten tersebut tidak merata sepanjang tahun sehingga jika mekanisme stok belum berjalan dengan baik maka produksi saat in season (panen raya) tidak mampu mencukupi kebutuhan saatout of season(paceklik). Agar mekanisme persedian bisa diketahui maka diperlukan kegiatan untuk mengetahui permintaan dan penawaran bawang merah dengan baik sehingga pendistribusian bawang merah di Jawa Barat bisa dilakukan dengan baik mengingat sebagian besar kabupaten/kota lainnya merupakan wilayah konsumen yang sangat tergantung kepada hasil produksi dari kabupaten sentra produksi bawang. Untuk lengkapnya dapat dilihat pada tabel dibawah ini.

Tabel 1. Luas Panen, Produksi dan Produktivitas Bawang Merah per Kabupaten di Provinsi Jawa Barat Tahun 2013

\begin{tabular}{lcrrr}
\hline Kabupaten & $\begin{array}{c}\text { Luas } \\
\text { Tanam } \\
\text { (Ha) }\end{array}$ & $\begin{array}{c}\text { Luas } \\
\text { Panen } \\
\text { (Ha) }\end{array}$ & $\begin{array}{c}\text { Produksi } \\
\text { (Ton) }\end{array}$ & $\begin{array}{r}\text { Proporsi } \\
\text { produksi } \\
(\%)\end{array}$ \\
\hline Cirebon & 3.624 & 3.658 & 36.449 & 31,53 \\
Bandung & 2.983 & 2.195 & 31.683 & 27,41 \\
Majalengka & 2.148 & 2.150 & 23.686 & 20,49 \\
Garut & 1.958 & 1.967 & 19.728 & 17,07 \\
Kuningan & 244 & 237 & 2.218 & 1,92 \\
Lainnya & 315 & 1.050 & 1.823 & 1,58 \\
\hline Jawa Barat & 11.272 & 11.257 & 115.586 & 100,00 \\
\hline Sumber: BPS Diolah & & &
\end{tabular}

Bedasarkan berbagai uraian diatas, maka diperlukan adanya kajian tentang analisa penawaran dan permintaan bawang merah di Provinsi Jawa Barat.

\section{KERANGKA KONSEP}

Analisis permintaan dan penawaran bawang merah memberikan bantuan yang sangat berarti untuk memahami interaksi penjual dan pembeli di pasar sehingga dapat dipahami bagaimana perubahan penawaran dan permintaan mempengaruhi perubahan harga bawang merah serta implikasi dari perubahan itu kepada pendapatan petani-petani dan produsen lainnya. Dengan demikian pemerintah dapat menentukan kebijakan untuk menstabilkan harga barang bawang merah dan pendapatan petani.

Permintaan konsumen didefinisikan sebagai kuantitas suatu barang tertentu dimana sorang konsumen ingin dan mampu membelinya pada berbagai tingkat harga. Hubungan permintaan tersebut hanya menunjukkan hubungan secara teoritis antara harga dan kuantitas yang dibelinya per unit waktu (ceteris paribus). Harga dan kuantitas berbanding terbalik, oleh karena itu kurva permintaan berslope negatif. Hubungan terbalik ini yang disebut sebagai hukum permintaan.

Permintaan pasar didefinisikan sebagai pilihan berbagai kuantitas dari suatu produk dimana semua konsumen di dalam suatu pasar tertentu ingin dan mampu membeli pada berbagai tingkat harga, ceteris paribus.

Faktor-faktor utama yang mempengaruhi tingkat permintaan dapat dikelompokkan menjadi 4 kelompok yakni:

1. Jumlah penduduk dan distribusinya menurut unsur, daerah geografis, jenis kelamin dan lain-lain,

2. Pendapatan konsumen dan distribusinya,

3. Harga dan ketersediaan produk-produk lain dan jasa,

4. Selera dan preferensi konsumen.

Kempat faktor tersebut sering disebut faktor-faktor penentu permintaan. Faktorfaktor ini dianggap tetap untuk suatu tingkat tertentu dari fungsi permintaan, tetapi dengan perjalanan waktu, perubahan permintaan merupakan aspek penting dari perubahan harga.

Faktor waktu dalam penawaran sangat penting karena produk-produk pertanian bersifat musiman, yaitu bulanan atau triwulan 
atau tahunan sehingga suatu kenaikan harga di pasar tidak dapat segera diikuti dengan naiknya penawaran kalau panen belum tiba. Hal ini menunjukkan bahwa elastisitas harga atas penawaran adalah inelastis dalam jangka pendek. Selain itu pengaruh harga tidak dapat dibalikkan karena kenaikan jumlah yang ditawarkan, maka penurunan harga tidak akan mengembalikan jumlah yang ditawarkan ke tingkat semula.

Dalam jangka pendek harga hasil-hasil pertanian cendrung mengalami fluktuasi yang terkadang cukup tajam. Harga produk pertanian tersebut dapat mencapai harga yang sangat tinggi, namun juga sebaliknya dapat merosot ke harga yang sangat rendah, bahkan di bawah HPP. Ketidakstabilan harga tersebut dapat disebabkan oleh perubahan permintaan dan penawaran terhadap barang pertanian yang sifatnya tidak elastis. Hal ini menyebabkan perubahan yang sangat besar terhadap tingkat harga apabila permintaan atau penawaran mengalami perubahan. Dengan demikian faktor yang dapat menyebabkan ketidakstabilan harga pertanian dalam jangka pendek yaitu: (i) perubahan permintaan, (ii) perubahan penawaran.

Perubahan Penawaran. Tingkat produksi sektor pertanian sangat dipengaruhi oleh faktor-faktor yang berada di luar kemampuan para petani untuk mengendalikannya, salah satunya yaitu faktor alam seperti perubahan iklim. Selain itu, juga dipengaruhi oleh tingkat penerapan teknologi dan tingkat serangan hama dan penyakit. Akibatnya, produksi hasil pertanian relatif berbeda dari satu musim ke musim lainnya. Faktor-faktor ini salah satu penyebab tingkat produksi pertanian cenderung mengalami perubahan yang relatif besar kalau dibandingkan dengan perubahan produksi barang-barang industri.

Dikarenakan produk pertanian bersifat tidak elastis, maka dalam jangka panjang permintaan pendapatan terhadap barang-barang pertanian cenderung rendah, yaitu kenaikan dalam pendapatan hanya menimbulkan kenaikan yang kecil saja terhadap permintaan. Sementara, dalam jangka pendek disebabkan kebanyakan hasil-hasil pertanian merupakan barang kebutuhan pokok harian, yaitu digunakan tiaptiap hari sehingga walaupun harganya sangat meningkat namun jumlah yang sama masih tetap harus dikonsumsi. Sebaliknya pada waktu harga sngat merosot konsumsi tidak akan banyak bertambah karena kebutuhan konsumsi yang relatif tetap. Dengan demikian, harga produk pertanian akan mengalami perubahan yang sangat besar jika penawarannya mengalami perubahan.

Perubahan Permintaan. Peningkatan perekonomian nasional yang disertai dengan peningkatan pendapatan masyarakat serta pertambahan jumlah penduduk akan mempengaruhi permintaan terhadap barangbarang dan jasa-jasa, termasuk terhadap produk pertanian. Perubahan permintaan yang disebabkan oleh naik turunya perkembangan perekonomian ini akan menimbulkan perubahan harga. Akan tetapi sifat perubahan harga ini adalah berbeda untuk berbagai jenis barang. Barang-barang pertanian cendrung menngalami perubahan harga yang lebih besar dari pada harga barang-barang industri. Sifat perubahan yang seperti itu disebabkan karena penawaran terhadap barang-barang pertanian, seperti juga dengan permintaannya, yaitu tidak elastis.

Ada beberapa faktor yang menyebabkan penawaran terhadap barang pertanian bersifat tidak elastis, yaitu (1) barang-barang pertanian dihasilkan secara bermusim; (2) kapasitas memproduksi sektor pertanian cendrung untuk mencapai tingkat yang tinggi dan tidak terpengaruh oleh perubahan permintaan. Petani cendrung untuk secara maksimal menggunakan tanah yang dimilikinya. Pada waktu harga turun mereka akan bekerja giat dan berusaha mencapai produksi yang tinggi agar pendapatan mereka tidak dapat menaikkan produksi karena kapasitas produksi mereka (dalam jangka pendek) telah mencapai tingkat maksimal; dan (3) beberapa jenis tanaman memerlukan waktu bertahun-tahun sebelum hasilnya dapat diperoleh.

Teori Cobweb (dalam Mubyarto) menjelaskan siklus harga dan produksi yang naik turun dalam jangka waktu tertentu, yang pada dasarnya dapat dibedakan menjadi: (1) siklus dengan fluktuasi yang jaraknya tetap; (2) Siklus yang menuju titik keseimbangan; dan (3) Siklus yang menjauhi titik keseimbangan. Kondisi keseimbangan yang terjadi di pasar tentunya menjadi relatif tidak stabil apabila ada kekuatan-kekuatan yang mendorong harga dan jumlah barang atau komoditas yang pada akhirnya akan mencapai keseimbangan baru.

Berkaitan dengan aspek ini, di pasar ada kemungkinan akan terjadi kelebihan barang 
atau komoditas yang ditawarkan (surplus) dan kekurangan barang atau komoditas yang ditawarkan atau kelebihan barang atau komoditas yang diminta (shortage). Proses penyesuaian pasar menuju keseimbangan akan dipengaruhi oleh beberapa kondisi antara lain: (1) permintaan yang berubah, di mana penawaran tetap; (2) Penawaran yang berubah, di mana permintaan tetap; dan (3) Permintaan dan penawaran yang berubah secara simultan.

Dengan demikian, penawaran dan permintaan merupakan model ekonomi dari penentuan harga di pasar. Hal ini menyimpulkan bahwa dalam pasar yang kompetitif dengan harga satuan untuk suatu barang tertentu akan bervariasi sampai mengendap pada titik di mana kuantitas yang diminta oleh konsumen (harga berlaku) akan sama dengan kuantitas yang ditawarkan oleh produsen (harga berlaku), mengakibatkan ekonomi keseimbangan harga dan kuantitas. Empat hukum dasar penawaran dan permintaan:

1. Jika permintaan meningkat dan penawaran tetap tidak berubah, maka menyebabkan harga keseimbangan yang lebih tinggi dan kuantitas.

2. Jika permintaan menurun dan pasokan tetap tidak berubah, maka menyebabkan harga keseimbangan yang lebih rendah dan kuantitas.

3. Jika kenaikan permintaan dan penawaran tetap tidak berubah, maka menyebabkan harga keseimbangan yang lebih rendah dan kuantitas lebih tinggi.

Jika pasokan berkurang dan permintaan tetap tidak berubah, maka itu mengarah pada harga yang lebih tinggi dan kuantitas yang lebih rendah.

\section{METODE PENELITIAN}

Metode penelitian yang dipergunakan dalam penelitian ini adalah metode kualitatif. Penelitian dilakukan dengan teknik suatu kasus yang menggunakan data sekunder yang bersifat kurun waktu (time series) dari tahun $2009-2013$.

Sumber data dari BPS Provinsi Jawa Barat, Dinas Pertanian Tanaman Pangan Provinsi Jawa Barat dan badan Ketahanan Pangan Daerah Provinsi Jawa Barat. Selain itu juga ditunjang oleh data dan informasi yang diperoleh dari publikasi dan laporan-laporan yang terkait dengan penelitian ini.

\section{HASIL DAN PEMBAHASAN}

Perkembangan Luas Panen Bawang

Merah Jawa Barat. Pengembangan luas panen bawang merah di Jawa Barat bisa dilakukan melalui pengembangan dan perluasan areal sentra bawang merah untuk memenuhi kebutuhan dalam negeri baik konsumsi rumah tangga maupun industri dan juga dalam jangka panjang juga untuk memenuhi permintaan ekspor. Untuk memenuhi konsumsi bawang merah di Jawa Barat dengan perkiraan pertambahan jumlah penduduk tiap tahunnya cukup signifikan, pengembangan luas panen bawang merah diperlukan berdasarkan varietas yang disenangi untuk konsumsi di Jawa Barat perlu dilakukan. Berikut diperlihatkan perkembangan luas panen bawang merah Jawa Barat dan 5 kabupaten sentra bawang merah dari tahun 2009 - 2013.

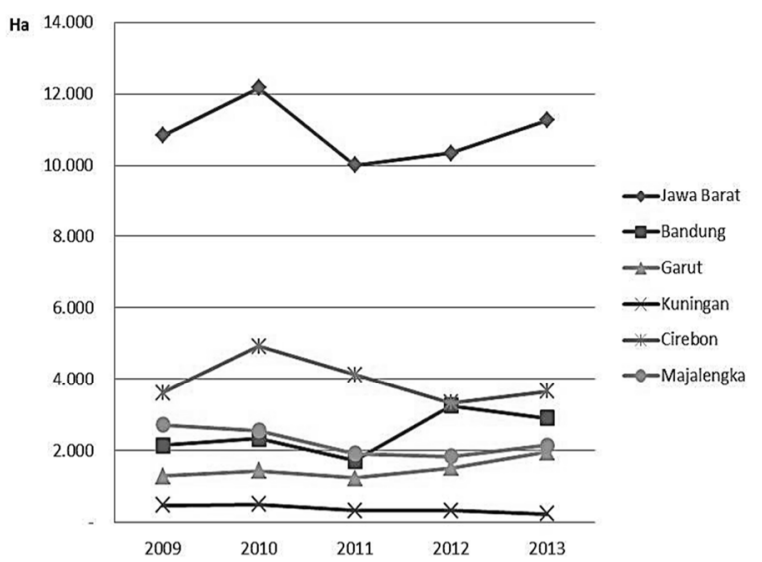

Gambar 1. Perkembangan Luas Panen Bawang Merah Jawa Barat dan 5 Kabupaten Sentra tahun 2009-2013.

Gambar 1 menunjukan tren perkembangan luas panen bawang merah di Jawa Barat mengalami fluktuasi luas panen dikarenakan jumlah luas tanam yang berkurang akibat dari perubahan iklim. Secara umum perkembangan luas panen bawang merah Jawa Barat tertinggi terjadi tahun 2010 dan mulai mengalami penurunan luas panen pada tahun 2011. Kabupaten Garut, Cirebon dan Majalengka memperlihatkan peningkatan luas panen pada tahun 2013 jika dibandingkan dengan tahun 2012 namun sebaliknya Kabupaten Bandung dan Kabupaten Kuningan mengalami penurunan luas panen pada tahun 2013 jika dibandingkan dengan tahun 2012. 
Tabel 2. Kontribusi Luas Panen Bawang Merah dari 5 Kabupaten Sentra Utama di Jawa Barat dan Lainnya Tahun 2009-2013

\begin{tabular}{|c|c|c|c|c|c|c|}
\hline \multirow{2}{*}{ Kabupaten } & \multicolumn{5}{|c|}{ Luas Panen (Ha) } & \multirow{2}{*}{ Share (\%) } \\
\hline & 2009 & 2010 & 2011 & 2012 & 2013 & \\
\hline Bandung & 2.150 & 2.333 & 1.721 & 3.259 & 2.915 & 22,66 \\
\hline Garut & 1.299 & 1.438 & 1.238 & 1.525 & 1.967 & 13,67 \\
\hline Kuningan & 483 & 504 & 329 & 339 & 237 & 3,46 \\
\hline Cirebon & 3.612 & 4.925 & 4.118 & 3.343 & 3.658 & 35,99 \\
\hline Majalengka & 2.727 & 2.562 & 1.917 & 1.842 & 2.150 & 20,50 \\
\hline Lainnya & 566 & 406 & 686 & 39 & 330 & 3,71 \\
\hline Jawa Barat & 10.837 & 12.168 & 10.009 & 10.347 & 11.257 & 100,00 \\
\hline
\end{tabular}

Sumber : BPS Jawa Barat (diolah)

Tabel 3. Kontribusi Produksi Bawang Merah dari 5 Kabupaten Sentra Utama di Jawa Barat dan lainnyaTahun 2009-2013

\begin{tabular}{|c|c|c|c|c|c|c|}
\hline \multirow{2}{*}{ Kabupaten } & \multicolumn{5}{|c|}{ Produksi (Ton) } & \multirow{2}{*}{$\begin{array}{c}\text { Share } \\
\text { Kumulatif } \\
(\%)\end{array}$} \\
\hline & 2009 & 2010 & 2011 & 2012 & 2013 & \\
\hline Bandung & 24.613 & 26.502 & 23.689 & 39.222 & 31.682 & - \\
\hline Garut & 13.052 & 13.378 & 9.860 & 15.064 & 19.728 & 25,44 \\
\hline Kuningan & 3.917 & 3.937 & 3.174 & 3.632 & 2.218 & 37,85 \\
\hline Cirebon & 41.898 & 47.408 & 41.442 & 29.395 & 36.449 & 40,80 \\
\hline Majalengka & 35.227 & 22.878 & 18.642 & 20.636 & 23.683 & 75,12 \\
\hline Lainnya & 4.882 & 2.293 & 4.468 & 7.948 & 1.825 & 96,26 \\
\hline Jawa Barat & 123.587 & 116.396 & 101.273 & 115.896 & 115.585 & 100,00 \\
\hline
\end{tabular}

Sumber : BPS Jawa Barat (diolah)

Tabel 2 memperlihatkan kontribusi luas panen dari 5 kabupaten sentra produksi utama bawang merah terhadap produksi bawang merah Jawa Barat selama periode tahun 20092013. Kontribusi luas panen bawang merah di 5 kabupaten kajian memperlihatkan bahwa Kabupaten Cirebon, Bandung dan Majalengka adalah tiga kabupaten utama penghasil bawang merah di Jawa Barat dengan kontribusi luas panen dari ke tiga kabupaten tersebut terhadap luas panen bawang merah Jawa Barat sebesar 79,15 persen. Dari data selama tahun 20092013, kontribusi luas panen bawang merah terbesar adalah Kabupaten Cirebon dengan presentase 35,99 persen kemudian Kab. Bandung, Kab. Majalengka, Kab Garut dan terakhir adalah Kab. Kuningan. Kontribusi terkecil dari 5 kabupaten tersebut terhadap luas panen bawang merah Jawa Barat adalah Kabupaten Kuningan sebesar 3.46 persen. Rata-rata kontribusi luas panen bawang merah dari ke-5 sentra utama bawang merah terhadap luas panen nasional adalah sebesar 96,29 persen sedangkan kabupaten lainnya sebesar 3,71 persen.

\section{Perkembangan Produksi dan}

Produktivitas Bawang Merah Jawa Barat.

Dari Gambar 2 diperlihatkan pola

perkembangan produksi bawang merah Jawa Barat dari data tahun 2009-2013 cenderung menurun dibandingkan tahun 2009 puncak penurunan terjadi di tahun 2011. Kontribusi produksi Jawa Barat terhadap nasional sebesar 11,73 persen menempati urutan ke tiga setelah Jawa Tengah dan Jawa Timur. Jika dilihat produksi bawang merah Jawa Barat periode tahun 2009 - 2013 produksi tertinggi terjadi pada tahun 2009 sebesar 123.587 ton dan produksi terendah terjadi di tahun 2011 sebesar 101.273 ton.

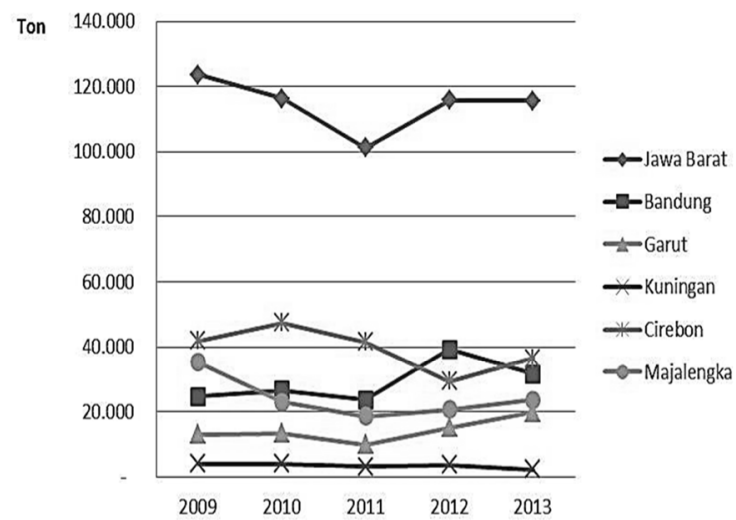

Gambar 2. Perkembangan Produksi Bawang Merah Jawa Barat dan 5 Kabupaten Sentra bawang Merah tahun 2009-2013.

Peningkatan perkembangan produksi di tahun 2009 dan 2010 lebih dikarenakan:

- Musim, Jika dibandingkan tahun lainnya pola musim tahun 2009 dan 2010 lebih 
stabil karena hanya 2 bulan kering, 9 bulan bulan hujan, dan 1 bulan kondisi normal

- Terjadi peningkatan permintaan bawang merah akibat dari peningkatan konsumsi per kapita mendorong peningkatan intensitas produksi bawang merah sehingga terjadi peningkatan perkembangan produksi bawang merah Jawa Barat. Rata-rata pertumbuhan produksi bawang merah di Jawa Barat mengalami peningkatan tertinggi pada tahun 2009 terendah di tahun 2011. Rata-rata perkembangan produksi bawang merah pada kabupaten Garut, Cirebon dan Majalengka pada tahun 2013 lebih tinggi dari tahun 2012 namun berbeda dengan kabupaten Bandung dan kabupaten lainnya cenderung produksi pada tahun 2013 turun jika dibandingkan dengna tahun 2012.

Pada periode tahun 2009 - 2013 untuk 5 kabupaten sentra bawang merah, produktivitas tertinggi adalah kabupaten Garut yang dicapai pada tahun 2011 dengan produktivitas 13,76 dan produktivitas terendah adalah Kabupaten Kuningan dengan produktivitas 7,81 persen. Dari 5 kabupaten, hanya Kabupaten Garut yang produktivitasnya meningkat pada tahun 2013 dibandingkan tahun 2012 sedangkan kabupaten lainnya mengalami penurunan termasuk produktivitas Jawa Barat terjadi penurunan pada tahun 2013.

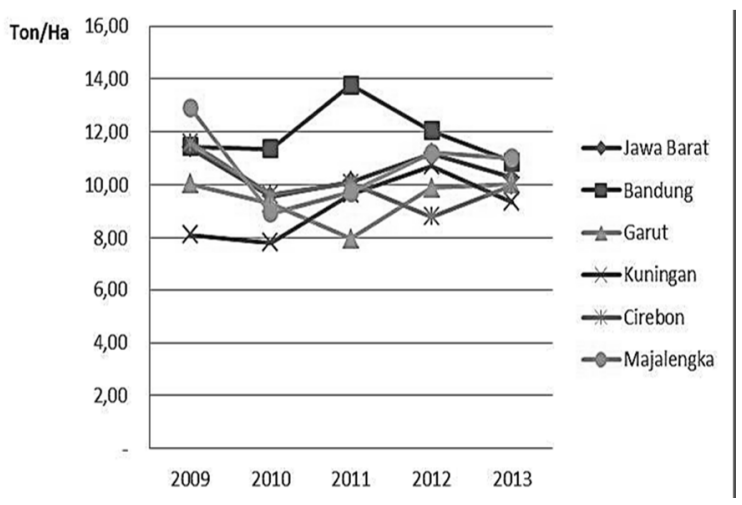

Gambar 3. Perkembangan Produktivitas Bawang Merah di Jawa Barat dan 5 Kabupaten Sentra Produksi tahun 2009-2013.

Secara umum dari tabel di atas, rata-rata pertumbuhan produktivitas bawang merah dari tahun 2009-2013 dari 5 kabupaten sentra bawang merah di Jawa Barat memperlihatkan bahwa produktivitas tertinggi adalah Kabupaten Garut dengan rataan produktivitas 11,21 ton/ha dan terendah adalah Kuningan dengan produktivitas 8,95 ton/ha. Tingginya produktivitas bawang merah di Kabupaten Garut jika dibandingkan dengan Kabupaten lain dikarenakan rotasi tanaman berjalan di Kabupaten Garut yang dilakukan sebagai berikut: pada saat musim hujan bawang merah di Kabupaten Garut ditanam di lahan kering (di gunung) dengan Varietas Tuktuk dan Maja sedang di sawah ditanam padi, pada saat musim kemarau di petani Garut khusus Bayongbong menanam bawang merah di lahan sawah dan di gunung (lahan kering) ditanam Jagung setelah tanam jagung akan tanam bawang merah lagi sehingga terjadi rotasi tanaman dan pemutusan berkembangnya OPT pengganggu.

\section{Penawaran Bawang Merah Jawa}

Barat. Penawaran bawang merah dalam kajian ini adalah jumlah bawang merah yang tersedia dipasar yang dapat dibeli atau dikonsumsi oleh konsumen sebagaimana cara perhitungan yang umum dipergunakan untuk menghitung Neraca Bahan Makanan (NBM). Oleh karena itu, dalam perhitungan penawaran bawang merah, produksi bawang merah dikurangi oleh faktor konversi disebabkan bawang yang diproduksi dalam keadaan bawang basah sementara yang umumnya diperdagangkan adalah bawang kering. Berdasarkan hasil penelitian dan hasil yang sama juga dipergunakan oleh BPS dan kementan dengan faktor konversi sebesar 70\% atau susut hasil karena pengeringan adalah sebesar 30\%. Selanjutnya, hasil produksi yang sudah dikeringkan tersebut (disebut sebagai "keluaran") dikurangi untuk penggunaan bibit sebesar $10 \%$, tercecer atau hilang hasil dalam kegiatan panen dan pasca panen sebesar 5\%. Hasil dari setelah pengurangan bibit dan tercecer tersebut merupakan penawaran bawang merah yang tersedia untuk dikonsumsi atau dibeli konsumen.

Pada Tabel 4. ditunjukkan hasil perhitungan penawaran bawang. Pada tabel tersebut juga menunjukkan bahwa sejak tahun 2009 , penawaran bawang merah menunjukkan kondisi yang berfluktuasi (terjadi kenaikan dan penurunan). Tidak stabilnya penawaran bawang merah tersebut ditentukan oleh besarnya luas panen dan tingkat produktivitas bawang merah. Penawaran bawang merah tertinggi terjadi pada tahun 2009, yaitu sebesar $71.680,75$ ton. Jika penawaran tersebut dibagi oleh jumlah penduduk di Provinsi Jawa Barat pada tahun yang sama tanpa memperhitungkan kebutuhan industri, maka menunjukkan 
Tabel 4. Penawaran Bawang Merah di Provinsi Jawa Barat

\begin{tabular}{lllllll}
\hline Komponen & Satuan & 2009 & 2010 & 2011 & 2012 & 2013 \\
\hline Luas Panen & ha & 10.837 & 12.168 & 10.009 & 11.438 & 11.257 \\
Produksi & ton & 123.587 & 116.395 & 101.272 & 115.896 & 115.585 \\
Keluaran & ton & 86.511 & 81.477 & 70.890 & 81.127 & 80.909 \\
Penggunaan untuk bibit & ton & 8.651 & 8.147 & 7.089 & 8.112 & 8.090 \\
Tercecer & ton & 6.179 & 5.819 & 5.063 & 5.794 & 5.779 \\
Ketersediaan Penawaran & ton & 71.680 & 67.509 & 58.738 & 67.219 & 67.039 \\
Ketersediaan per kapita & $\mathrm{kg} /$ kapita/tahun & 1,68 & 1,56 & 0,98 & 1,48 & 1,45 \\
\hline
\end{tabular}

Sumber : Dinas Pertanian dan Tanaman Pangan Prov Jawa Barat (diolah)

Tabel 5. Permintaan Bawang Merah di Provinsi Jawa Barat Tahun 2009 - 2013

\begin{tabular}{|c|c|c|c|c|c|c|}
\hline Komponen & Satuan & 2009 & 2010 & 2011 & 2012 & 2013 \\
\hline 1. Jumlah Penduduk & Orang & 41.501 .564 & 43.053 .732 & 43.826 .775 & 44.548 .431 & 45.756 .052 \\
\hline 2. Konsumsi per Kapita & $\mathrm{kg} / \mathrm{kapita} /$ tahun & 2,524 & 2,529 & 2,362 & 2,764 & 2,065 \\
\hline 3. Total Permintaan & Ton & $104.749,95$ & $108.882,89$ & $103.518,84$ & $123.131,86$ & $94.486,25$ \\
\hline
\end{tabular}

Sumber : Dinas Pertanian dan Tanaman Pangan Prov Jawa Barat (diolah)

penawaran bawang merah sebesar $1,68 \mathrm{~kg}$ $\mathrm{kg} / \mathrm{kapita} / \mathrm{tahun}$. Sementara itu, penawaran bawang merah terendah terjadi pada Tahun 2011 dengan tingkat penawaran bawang merah sebesar 58.738,22 ton atau sebesar 0.98 $\mathrm{kg} / \mathrm{kapita} / \mathrm{tahun}$.

Permintaan Bawang Merah Provinsi

Jawa Barat. Permintaan bawang merah dalam kajian ini adalah permintaan konsumen rumah tangga tanpa memperhitungkan kebutuhan industri. Hal tersebut disebabkan tidak diperolehnya data kebutuhan industri pengolahan pangan yang menggunakan bahan baku bawang merah. Oleh karena itu, perhitungan permintaan bawang merah dalam kajian ini adalah jumlah penduduk dikalikan dengan konsumsi kg/kapita/tahun. Perhitungan permintaan ini tentunya masih mengandung kelemahan karena diasumsikan penduduk dari bayi hingga dewasa mengkonsumsi bawang merah dengan jumlah konsumsi yang sama, padahal setiap kelompok umur mengkonsumsi dengan jumlah yang berbeda dan bayi juga tidak mengkonsumsi bawang merah. Selain itu perhitungan permintaan bawang merah ini juga mengabaikan keunikan daerah yang berbeda jumlah penggunaan bawang merahnya sebagai bumbu masakannya.

Tabel 5. memperlihatkan bahwa sejak tahun 2009 - 2013, sebagaimana halnya penawaran bawang merah, maka permintaan bawang merah pun menunjukkan kondisi yang berfluktuasi (terjadi kenaikan dan penurunan). Berfluktuasinya permintaan bawang merah tersebut sangat tergantung kepada besarnya konsumsi per kapita, walaupun jumlah penduduk di Provinsi Jawa Barat Cenderung memiliki tren yang meningkat namun jika konsumsi per kapitanya turun dapat menyebabkan tingkat permintaan pun turun. Hal tersebut diperlihatkan pada Tahun 2011, walaupun jumlah penduduk pada tahun 2011 meningkat dengan laju pertumbuhan penduduk sebesar $1,76 \%$ namun terjadi penurunan konsumsi perkapita sebesar $-0,05 \%$ dari 2,529 $\mathrm{kg} / \mathrm{kapita} /$ tahun menjadi 2,362 kg/kapita/tahun. Tingkat permintaan tahun 2013 menjadi permintaan bawang merah terendah sejak tahun 2009, yaitu sebesar 94.486,25 ton. Penurunan ini berkisar sekitar 23,26\% dari permintaan tahun sebelumnya padahal jika melihat jumlah penduduk malah meningkat sekitar $2,7 \%$ dari tahun sebelumnya. Penyebab penurunan permintaan ini salah satunya disebabkan oleh menurunnya tingkat konsumsi bawang merah $\mathrm{kg} / \mathrm{kapita} /$ tahunnya yaitu 2,065 turun sekitar 25,29\% dari pada tahun sebelumnya. Permintaan bawang merah tertinggi terjadi pada tahun 2012, yaitu sebesar $123.131,86$ ton.

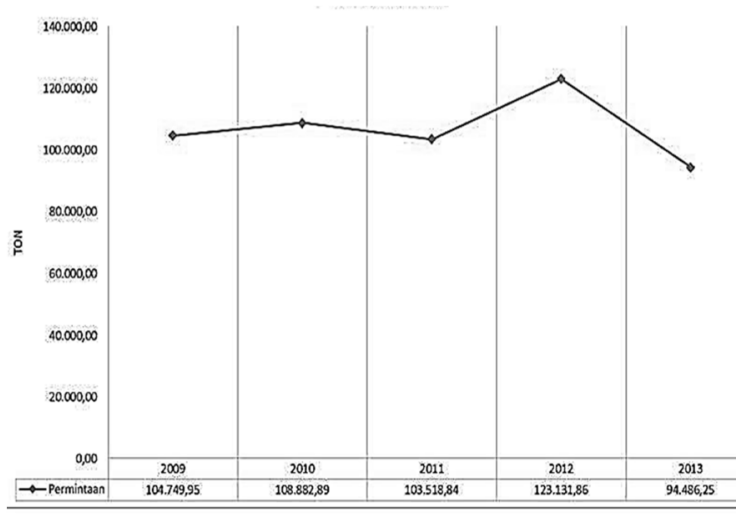

Gambar 4. Permintaan Bawang Merah di Provinsi Jawa Barat tahun 2009-2013. 
Hal ini selain disebabkan adanya peningkatan pertumbuhan jumlah penduduk sebesar $1,65 \%$ dari tahun sebelumnya, selain itu adanya peningkatan tingkat konsumsi perkapita bawang merah sebesar $17,02 \%$, kedua hal tersebut adalah penyebab utama meningkatnya permintaan bawang merah pada tahun 2012. Namun demikian, jika dirataratakan tiap tahunnya permintaan konsumsi bawang merah di Provinsi Jawa Barat mempunyai kecenderungan tren yang stabil atau tetap (Gambar 4).

\section{Analisis Surplus Defisit Bawang} Merah di Provinsi Jawa Barat. Analisis surplus defisit ini hanya menggambarkan bagaimana produksi di suatu provinsi mencukupi kebutuhan konsumsi masyarakat di dalam provinsi tersebut dengan mengabaikan pergerakan aliran bawang merah yang bergerak dari titik produksi ke titik konsumsi. Artinya, analisis surplus defisit menekankan bahwa pergerakan aliran bawang merah dari titik produksi ke titik konsumsi hanya terjadi di dalam satu provinsi yang sama saja. Bawang merah diperdagangkan ke luar provinsi jika terjadi surplus di provinsi tersebut.

Provinsi Jawa Barat merupakan salah satu sentra produksi bawang merah nasional, namun pada saat yang bersamaan juga merupakan provinsi dengan kebutuhan bawah merah terbesar di tingkat nasional. Permintaan yang sangat besar tersebut disebabkan Provinsi Jawa Barat merupakan provinsi dengan jumlah penduduk terbesar. Di lihat dari sisi produksi dan penawaran menunjukkan bahwa dalam 5 tahun terakhir produksinya relatif tidak berubah, sedangkan jumlah penduduknya meningkat terus. Keadaan ini menyebabkan Provinsi Jawa Barat selalu defisit bawang merah walaupun produksi bawang merahnya merupakan provinsi penghasil bawang merah ketiga terbesar setalah Jawa Tengah dan Jawa Timur.

Provinsi Jawa Barat selalu defisit bawang merah setiap tahunnya dengan ratarata tingkat defisit sebesar $-40.516,39$ ton per tahun, dengan naik dan turun permintaan yang bervariasi pada tiap tahunnya. Defisit terbesar antara tahun 2009 - 2013 terjadi pada tahun 2012 yaitu memiliki defisit permintaan bawang merah sebesar 55.911,95 ton.

Gambar 5 menunjukan perbandingan antara produksi (keluaran) dan permintaan bawang merah di Provinsi Jawa Barat, dapat dilihat bahwa pada setiap tahunnya dari tahun
2009 - 2013 Provinsi Jawa Barat selalu mengalami defisit.

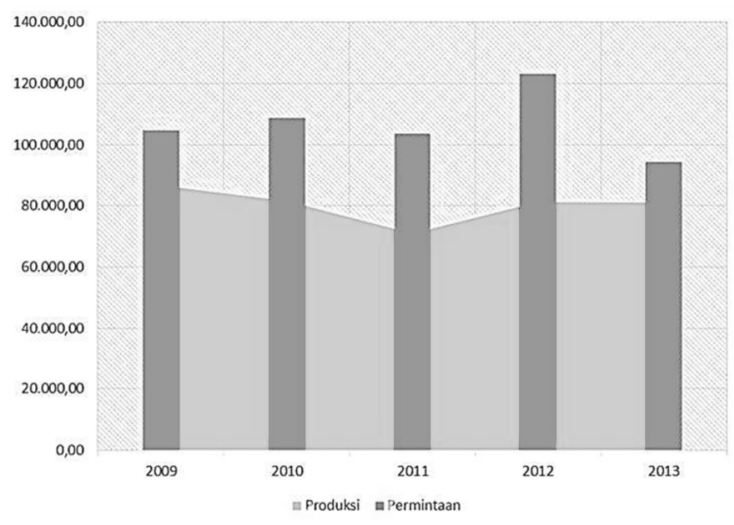

Gambar 5. Perbandingan antara Produksi dan Permintaan Bawang Merah di Provinsi Jawa Barat tahun 2009-2013.

\section{KESIMPULAN}

Provinsi Jawa Barat merupakan salah satu sentra produksi bawang merah nasional, namun pada saat yang bersamaan juga merupakan provinsi dengan kebutuhan bawah merah terbesar di tingkat nasional. Permintaan yang sangat besar tersebut disebabkan Provinsi Jawa Barat merupakan provinsi dengan jumlah penduduk terbesar. Di lihat dari sisi produksi dan penawaran menunjukkan bahwa dalam 5 tahun terakhir produksinya relatif tidak berubah, sedangkan jumlah penduduknya meningkat terus. Keadaan ini menyebabkan Provinsi Jawa barat selalu defisit bawang merah walaupun produksi bawang merahnya merupakan provinsi penghasil bawang merah ketiga terbesar setalah Jawa Tengah dan Jawa Timur.

Provinsi Jawa Barat selalu mengalami defisit bawang merah, maka seyogyanya pemerintah dianjurkan untuk membuat kebijakan agar Provinsi Jawa Barat paling tidak dapat memenuhi kebutuhan nya sendiri. Langkah yang dapat dilakukan adalah melalui beberapa kebijakan seperti: 1) Peningkatan luas tanam disertai dengan upaya pengembangan teknologi umtuk meningkatkan produktivitas bawang merah; 2) Melakukan pengendalian laju pertumbuhan penduduk; dan 3) Dilakukan upaya agar ritme terjadinya peningkatan konsumsi per kapita sebagaimana periode sebelumnya dapat dikurangi, karena bawang adalah bahan masakan bukan produk pertanian yang dikonsumsi langsung, yang permintaannya relatif tetapwalaupun pendapatan masyarakat meningkat. 


\section{UCAPAN TERIMA KASIH}

Terima kasih kepada Badan ketahan Pangan Daerah (BKPD) Provinsi Jawa barat dan Dinas Pertanian Tanaman Pangan Provinsi Jawa Barat yang telah memberikan informasi dan data sehingga kajian ini dapat dilaksanakan.

\section{DAFTAR PUSTAKA}

BPS. (2013). Berita Resmi Statistik No. 54/08/ Th. XVI, 1 Agustus 2013.

BPS Provinsi Jawa Barat. (2015). Jawa Barat Dalam Angka 2008-2014.

Mubyarto. 1989. Pengantar Ekonomi

Pertanian. Jakarta : LP3ES

RPJMN Bidang Pangan Dan Pertanian 2015-
2019. (2013). Direktorat Pangan Dan

Pertanian Kementerian Perencanaan

Pembangunan Nasional/Badan

Perencanaan Pembangunan Nasional.

Rizky P,Aditya. (2013). Pengaruh Produksi,

Konsumsi Dan Harga Terhadap Impor

Bawang Merah di Kabupaten Brebes

Tahun (2006.01 - 2010.12). Jurusan

Ekonomi Pembangunan Fakultas

Ekonomi Universitas Negeri Semarang. Wahyudin, Moch. Maksum, Moch. Yuliando,

Heny (2015). The Shallot Pricing in the View of Import Restriction and Price Reference.Agriculture and Agricultural Science Procedia 3 (2015) 132- 136. ELSEVIER 